\title{
"El Sistema de Franchising y la Tutela de los Consumidores y Usuarios en el Derecho Argentino"*
}

\author{
Ollanuel Quiñas Podxiguer
}

Professor de Direito Civil e Comercial da Faculdade de Direito da Universidade de Buenos Aires, Argentina

\begin{tabular}{|c|}
\hline SUMARIO \\
1. Consideraciones liminares de aproxi- \\
mación al objeto. Caracterización básica del \\
"Sistema de Franchising". \\
2. Conceptos claves del negocio. \\
3. Responsabilidad ante los consumido- \\
res y usuarios por daños derivados de pro- \\
ductos elaborados defectuosos. \\
4. Responsabilidad ante los usuarios de- \\
rivada de la prestación de servicios defec- \\
tuosos. \\
5. Responsabilidad ante los consumido- \\
res y usuarios por eventuales daños deriva- \\
dos de los riesgos del desarrollo. \\
6. Reflexiones últimas.
\end{tabular}

1. Consideraciones liminares de aproximación al objeto. Caracterización básica del "Sistema de Franchising".

ifícilmente los ex combatientes 1 norteamericanos del Frente Aliado durante la Segunda Guerra Mundial primero', y el "Henry Ford de las hamburguesas" después', hayan previsto en su día las consecuencias económicas, jurídicas y aún sociales del "Sistema" que en virtud de ellos, principalmente, alcanzó el grado de desarrollo cuantitativo y cualitativo que presenta en la actual posmodernidad.

Trabalho apresentado no curso organizado pelo mestrado em direito da UFRGS, I Jornada, sobre dano a pessoa e ao consumidor no direito brasileiro e argentino, 02 e 03 de junho de 1997.

1. Marzorati, Osvaldo J., Derecho de los negocios internacionales, Astrea, Bs. As., 1993, pág. 430, donde puede leerse que "la gran expansión que se da en materia de franquicia, se percibe claramente recién después de la Segunda Guerra Mundial, en los EE. UU., cuando se desarrolla el business format franchising. Fue la respuesta más adecuada que tuvieron individuos con poca o ninguna experiencia en el manejo de una empresa, para llevar adelante y desarrollar una actividad empresaria, y sortear los innumerables riesgos que ella traía".

2. Nominación metatórica, pero significativa, que, entre otros, asigna Donald D. Boroian a Ray Kroc, artífice del imperio económico "McDonald's"; una sumaria exposición de la historia de este personaje casi mítico puede leerse en la Obra del mismo Boroian, Las ventajas del Franchising, Ediciones Macchi, Bs. As., 1993, pág. 72. 
Los primeros necesitaban una salida no marginal que les posibilitara reinsertarse laboral y socialmente en la comunidad norteamericana, contando cada uno de ellos a su "regreso a casa" con un capital prome dio acumulado de U\$S 20.000 - que en su día representaba un poder adquisitivo muy superior al actual -, que era el resultado de pago, por parte de la Unión, de los servicios bélicos prestados ${ }^{3}$. Sujetos pragmáticos y avizores los invitaron entonces a "estre char filas" una vez más, pero en esta oportunidad tras la bandera del Franchising, casi convirtiéndolos tras ello en auténticos "self made men" y en paradigmas del "sueño americano".

El segundo citado, Ray Kroc, deseaba saber porque sus mejores clientes eran sus mejores clientes, de modo de lograr que los que no lo eran lo fuesen. Con tal finalidad acudió en el año 1954 a San Bernardino, California, y contactó a Dick y Mac McDonald. Y prontamente advirtió que era más prometedor dedicarse a pulir $y$ expandir el negocio de "comidas rápidas" que aplicarse a la venta de batidoras ${ }^{4}$.

Con lo que se lleva narrado es suficiente para comenzar a despejar un prejuicio bastante común entre quienes por motivos diferentes, pero encuadrados esen cial o mayormente en la órbita del Dere. cho, tenemos ocasión, deseo o necesidad de aproximarnos al Franchising. Esto es considerar que se trata de un contrato o, por mejor decir, de una Forma Moderna de Contratación, lo que si bien es admisible con fines pedagógicos para atribuir su estudio en el ámbito de una asignatura integrante de la Currícula de la Carrera de Abogacía - como ser Contratos Civiles y Comerciales -, no es suficiente para posibilitar una visión amplia, sistémica, del objeto cognoscible por parte del sujeto cognoscente.

En su génesis misma el Franchising es un "concepto de hacer negocios", un Sistema de distribución y expansión comercial - el más obsesivamente elaborado y perfeccionado de todos -, una suerte de "marke ting de la idea" al decir de algunos ${ }^{5}$, que permite la creación de una "imagen de distribución" en cadena, sea de productos servicios o derechos de casi cualquier ín dole, que orquestadamente posibilita impactar en prácticamente todo tipo de mercados a potenciales consumidores o usuarios $^{7}$

El contrato de franquicia individua será en todo caso una de las herramientas o instrumento final del cual se valdrán formalmente quienes legítimamente aspiren a concretar el referido negocio mercantil ${ }^{8}$.

3. Referido por Adrián Giménez Hutton en el Curso de Posgrado de Franchising, Facultad de Derecho y Cs. Sociales, UBA, 1995 El nombrado es integrante del Directorio de Francorp Argentina, y miembro de la Asociación Argentina de Franchising.

4. Kroc tenía los derechos de comercialización de una batidora de cinco ejes denominada "Multimixer", que constituia su "producto de venta".

5. Santini, Gerardo, El Comercio. Ensayo de Economía del Derecho, Ariel, Barcelona, 1988, págs. 86 y sgtes.

6. Farina, Juan M., Contratos comerciales modernos, Astrea, Bs. As., 1994, pág. 455

7. Boroian explica que "para entender el éxito del Franchising, se debe comprender primero que significa: el Franchising es una estrategia de crecimiento comercial única regida por un conjunto de reglas únicas", Las ventajas del Franchising, Ediciones Macchi, Bs. As., 1993, pág. 13

8. "El contrato, como herramienta jurídica de acceso a los bienes y servicios .......", Ghersi, Carlos A., Contratos civiles y comerciales, Astrea, Bs. As., 1994, T I, pág. V. Las licencias, permisos de utilización, manual de operaciones, etc., serán otras, vinculadas a aquél.

Revista da Faculdade de Direito da UFRGS, v. 13, 1997
Podrá pensarse que lo anterior es predicable de casi toda figura contractual, y se estará probablemente en lo cierto. Pero en pocos casos como en el del Franchising el Derecho Contractual strictu sensu se ve "excedido" por el fenómeno económico; de ahí que comprenderlo así sea determinante para poder "aprehenderlo" jurídicamente de modo de no desnaturalizarlo por un lado, y adecuarlo a las exigencias y estándares sociales por el otro.

Como consecuencia de su éxito comercial, el Franchising "constituye uno de los acontecimientos económicos más significativos del siglo XX", lo que ha posibilitado a quienes se dedicaron a este emprendimiento - franquiciantes, principalmente, y también franquiciados - el conseguir una también significativa acumulación y reproducción del capital originalmente invertido ${ }^{10}$.

La Doctrina científica que en el ám bito del Derecho ha abordado el fenómeno del Franchising se ha ocupado de intentar sistematizar, y en forma no siempre coincidente, las distintas clases o clasificaciones del Franchising ${ }^{11}$. Básicamente puede enunciarse como posibles variantes el Franchising de producto, el Franchising de servicio, el Franchising de marca registrada,

el Franchising master, el Franchising de conversión y el Franchising de empresa o business format Franchising. Este último es precisamente la "franquicia en sentido próprio" 12 , y constituye la forma más evolucionada, perfeccionada y abarcadora del Franchising ${ }^{13}$, comprensiva de elementos tales como la licencia de uso de marcas, la transmisión del know how to do it - saber como hacer -, asistencia técnica del franquiciado, plan de publicidad, régimen de pago de derechos y regalías, etc., y ella será por tales motivos la que se tendrá principalmente en consideración en orden al análisis en el presente trabajo de los distintos tipos de responsabilidades de franquiciante y franquiciados en relación a consumidores y usuarios, cuyos resultados son perfectamente extrapolables a las otras clases de Franchising enunciados. Naturalmente que en tanto sea imprescindible metodológicamente referirse a alguna forma del Franchising en especial así se lo destacará y, de ser necesario, se procederá a la descripción de sus notas características típicas.

Hace también al tema convocante destacar ab initio algunos de los caracteres o notas esenciales del contrato de franquicia individual.

9. Boroian, Donald D., Las ventajas de Franchising, Ediciones Macchi, Bs. As., 1993, pág. 21.

"Luego de 20 años, el valor de una sola acción - de McDonald's - había aumentado aproximadamente 175 veces el precio de la oferta inicial", Boroian, Donald D., Las ventajas de Franchising, Ediciones Macchi, Bs. As., 1993, pág. 28.

11. Ver Chervin de Katz, Marta, ¿Qué es el Franchising?, Abeledo-Perrot, Bs. As., 1995, pág. 11 y sgtes.; Farina, Juan M., Contratos comerciales modernos, Astrea, Bs. As., 1994, pág. 457 y sgtes.; Kleidermacher, Jaime L., Franchising, Abeledo-Perrot, Bs. As. 1995, pág. 105 y sgtes., Ghersi, Carlos A., Contratos civiles y comerciales, Astrea, Bs. As., 1994, T II, pág. 41 y sgtes.; Zaldivar, Enrique, Acotaciones sobre el contrato de "franquicia", LL-1992-B-1143.

12. Marzorati, Osvaldo J., Derecho de los negocios inemacionales, Astrea, Bs. As., 1993, pág., 440

13. Llamada también "negocio llave en mano o paquete", Zullo, Nicolás S. R., Franquicia o concesión, en Boletín Económico de La Ley, 26-06-90, citado por Farina, Juan M., Contratos comerciales modernos, Astrea, Bs. As., 1994, pág. 457.

Revista da Faculdade de Direito da UFRGS, v. 13, 1997 
Una de esas notas es el carácter fiduciario o de confianza que presenta el contrato en $\mathbf{s}^{14}$. Es que dada la estrechez de múltiples relaciones que vincularán a las partes o centros de interés económica y jurídicamente, de no existir tal confianza no se involucrarían al grado que deben hacerlo para aspirar al éxito en el emprendimiento común. Y esta nota tendrá inclusive relevancia en la etapa poscontractual, una vez extinguidos los efectos principales de la relación convencional vinculante - verbigra cia, no develación por parte del franquiciado del know how al que hipotéticamente haya tenido acceso -.

El rasgo fiduciario va conectado inescindiblemente a las personas del caso; de ahí que ello, junto con otras cualidades requeridas de las mismas, determine que la franquicia sea "inherente a las personas" recíprocamente escogidas, o intuitu personae. Al franquiciante le interesará un determinado perfil de franquiciado para integrar y prestigiar a su red o cadena, y al franquiciado potencial le interesará un determinado "estilo de hacer negocios" y no otro ergo, le interesará un franquiciante y no otro. Las obligaciones emergentes de perfeccionamiento del contrato deberán ser particularmente cumplidas, y de un modo determinado y esperado, por ciertos suje-

tos de derecho y no por otros. Esto está receptado normativamente en los arts. 498 , 626, 730, 1195 y 1196 Cód. Civil, entre otros, y si bien mayormente el carácter indicado es de aplicación a las obligaciones de hacer no fungibles, también hay inherencia a la persona en cuanto a las obligaciones de no hacer especificadas en la franquicia individual, toda vez que quien debe abstenerse, por hipótesis de ejemplo, de divulgar secretos integrantes del know how y eventualmente de competir con el franquiciante, es el franquiciado en cuestión y no otra persona física o jurídica distinta de él ${ }^{15}$.

Por lo general se prevé expresamente a nivel convencional que el franquiciado no podrá ceder su posición contractual en relación al franquiciante, salvo expreso consentimiento de este último ${ }^{16}$, lo cual reafirma la inherencia a su respecto. En sentido inverso nada se contempla habitualmente. Pero va de suyo que la inherencia del franquiciante, en caso de tratarse de una persona jurídica, que es la regla, tiene relación con su estrucutura y estilo negocial, y no con la composición circunstancial de capital accionario ni con las personas físicas que dirigen o administran a la Sociedad en determinado momento ${ }^{17}$. Es por ello que alguna Doctrina entiende este carácter en

14. Kleidermacher, Jaime L., Franchising, Abeledo-Perrot, Bs. As., 1995, pág. 136.

15. Parecería que, en contra de lo expresado, Oscar Ameal considera sólo intuitu personae a las obligaciones de hacer no fungibles, conf. Alterini, Atilio A., Ameal, Oscar J. y López Cabana, Roberto M., Curso de Obligaciones, Abeledo-Perrot, Bs. As., 1984, To II, pág. 142.

16. Es más prudente la prohibición categórica, dado que ante un eventual desacuerdo luego de celebrado el contrato, y de acudirse a sede judicial, el eventual Juzgador en virtud de la atipicidad de la figura de la franquicia podría verse tentado a aplicar lo prescripto en el art. 1598, Cód. Civil, en íntima conexión con el art. 1071 del mismo Cuerpo normativo.

17. Ray Kroc falleció en 1984; ya antes de eso, pero principalmente después, Fred Turner controlaba McDonald's, y ello no detuvo e ritmo de crecimiento de la red y ni siquiera fue advertido, de seguro, por la mayor parte de los franquiciados dado que el "estilo" permanecí esencialmente inalterado; conf. Boroian, Donald D., Las ventajas del Franchising, Ediciones Macchi, Bs. As., 1993, pág. 73.

Revista da Faculdade de Direito da UFRGS, v. 13, 1997 relación al franquiciante como intuitu instrumenti o inherencia relativa a las aptitudes técnicas y eficacia de la Empresa en cuestión ${ }^{18}$.

Otra característica típica de la franquicia individual es la de conformarse a través de un contrato estándar o uniforme, de aplicación para todos los potenciales adherentes a la red, cuyo contenido son cláusulas predispuestas por el franquiciante las que dada su inmodificabilidad asumen el rol de condiciones generales de contratación o condiciones negociales generales, lo que determina que cada franquicia otor gada constituya un contrato por adhesión ${ }^{19}$, en el cual la clásica "libertad de contratación" decimonónica, en relación al poten cial franquiciado, carecería de uno de sus componentes, esto es la posibilidad de convenir paritariamente el contenido contractual $^{20}$. La finalidad misma del Franchising impone lo descripto, en orden a preserva el estilo negocial propuesto, y a su turno impuesto, por el franquiciante; en definitiva es la uniformidad la que posibilitará con solidar una "imagen de distribución" determinante del éxito de las partes vincu ladas convencionalmente, susceptible de ser

lograda sólo a través de la adhesión ${ }^{21}$. Desde luego que lo descripto es extensible al Manual de Operaciones, al cual necesariamente remitirá el contrato de franquicia individual, y en donde estarán minuciosamente detallados todos los aspectos operativos del negocio en sí.

También la bilateralidad es una nota tipificante de la franquicia, en el sentido de que "las partes se obligan recíprocamente la una hacia la outra" - art. 1138, in fine, Cód. Civil -. Pero si bien entonces en lo interno de la relación convencional puede postularse que franquiciante y franquiciado son partes o centros de interés en un "negocio jurídico de cambio", dado que hay contraposición de intereses -verbigracia, percepción de derecho de ingreso y regalías para el franquiciante, a "cambio" del negocio "llave en mano" para el franquiciado-, en lo externo hay una evidente yuxtaposición de intereses tendiente a la obtención del éxito comercial y económico de todos los integrantes de la red, lo que permite afirmar que se está en presencia, analizado ello "desde afuera" principalmente, de un contrato plurilateral o de organización ${ }^{22}$.

18. Citado ello por Kleidermacher, Jaime L., Franchising, Abeledo-Perrot, Bs. As., 1995, pág. 134, quien entiende que el contrato de franquicia no es intuitu personae en relación al franquiciante y, en ciertos tipos de Franchising, tampoco en relación al franquiciado.

19. Para profundizar en estos conceptos puede verse Fatina, Juan M., Contratos comerciales modemos, Astrea, Bs. As., 1994, pág. 55 , en especial, y sgtes.

20. Sólo excepcionalmente, y por lo general atendiendo a circunstancias objetivas, v.gr.: zona geográfica, y mayormente en los inicios de la conformación de la red en determinado mercado, serían posibles y hasta convenientes diferencias de contenido contractual en relación a cuestiones no principales del negocio, v.gr: precios indicativos ligeramente diferenciados, distintos montos de derechos de ingreso a la red y/o de regalías periódicas, no imperatividad de compra a determinados proveedores por razones de costos comparativos atendiendo a las distancias, etc.

21. "Es la uniformidad del producto y el control de su calidad y distribución lo que causa la atención del público hacia los negocios de tranquicia que lo comercializan" (del leading case "Susser vs. Carvel Corp."), citado por Kleidermacher, Jaime L., Franchising, franquicia que lo comercializan" (del leading case "Sug
Abeledo-Perrot, Bs. As., 1995, pág. 140, nota 132.

22. Puede verse al respecto lo expuesto por Isaac Halperín en Curso de Derecho Comercial, Depalma, Bs. As., 1982, Vol. 1, pág. 211, en especial la cita de Brunetti. 
Y lo anterior se conecta con otro rasgo definitorio de la franquicia, esto es que se trata de un contrato de colaboración comercial $^{23}$ por requerirse de la acción común de las partes para lograr juntos lo que no les resultaría posible por separado ${ }^{24}$. Pero es relevante destacar sin embargo, que en ocasiones tras la cooperación formal se esconde una dominación sustancial ${ }^{25}$, y esto es precisamente lo que se da en el Franchising, dado que es el franquiciante cooperante quien dirige al franquiciado co-operado, pese a ser este último un sujeto de derecho formalmente independiente a nivel jurídico. Por ello Farina cita a Álvaro Órtiz de Zárate y advierte que ....... "en la realidad de los hechos es el franchisor quien impone las condiciones y el franchisee se somete"26.

No es ocioso referir enunciativamente algunos de los deberes que asume convencionalmente el franquiciante, los que tendrán como contrapartida - dada la bipolaridad de la obligación en sentido técnico jurídico - derechos en cabeza del franquiciado $^{27}$. Aquellos pueden ser: a) cesión de licencia de uso de marca; b) redacción y entrega del Manual de Operaciones; c) entrenamiento del franquiciado y de su personal; d) transmisión del know how; e) transmisión de estándares de calidad y servicio; f) asistencia permanente a nivel de compras, gerenciamiento, ventas y en el

plano de lo técnico y contable, etc.; g) implementación del plan de publicidad; $h$ ) actualización del Plan Negocial; etc.

También tendrá el franquiciante derechos específicos en relación al franquiciado, siendo algunos de los más habituales: a) percepción de derechos y regalías; b) imposición del sistema contable; c) información constante de la evolución de la ejecución del Plan Negocial, y de la situación económica y financiera del franquiciado; d) fijación de precios indicativos u obligatorios; e) determinación de proveedores de insumos; f) elección y/o aprobación del sitio físico en donde se instalará el establecimiento mercantil; g) exigencia e imposición efectiva de disciplina de grupo; h) determinación de pautas poscontractuales en orden a no utilización de marca, no revelación del know how, no competencia, etc., por parte del franquiciante; i) control permanente del franquiciado ejercido a través de la supervisión, dirigido a la detección de incumplimientos contractuales o fallas en la ejecución del Plan Negocial y a la evitación de perjuicios sobrevinientes para la red en general, y para el propio franquiciante en particular; etc.

Amerita que también se haga notar que la clásica Responsabilidad Civil tiene

23. Farina, Juan M., Contratos comerciales modernos, Astrea, Bs: As., 1994, pág. 455.

24. Característico también de figuras como el Joint Venture.

25. Susceptible de darse también en otros tipos de contrataciones, sobre todo cuando los Derechos intelectuales son objeto mediato de las mismas, como ser en los Contratos de Cooperación Tecnológica.

26. Farina, Juan M., Contratos comerciales modernos, Astrea, Bs. As., 1994, pág. 455.

27. Para derechos y deberes de las partes puede consultarse a Farina, Juan M., Astrea, Contratos comerciales modernos, Bs. As., 1994, págs. 459 y sgtes. y Kleidermacher, Jaime L., Franchising, Abeledo-Perrot, Bs. As., 1995, págs. 151 y sgtes. como sucedáneo posmoderno al Derecho de Daños; y ello no en virtud de sutilezas nominativas sino porque ha variado el norte. Antes se centraba el sistema de la Teoría General de Responder en torno al agente causal del daño, victimario, dañador, perjudicante o incumpliente; ahora la diana es el costado de la víctima, dañado, perjudicado o defraudado. De ahí que se haya cambiado "el sentido de la responsabilidadsanción hacia la responsabilidad-reparación"28. Ello aparejó como consecuencia no única - privilegiar el binomio "víctima relación de causalidad" por sobre el integrado por el par "victimario - factor de atribución". Y todo ello enderezado a posibilitar el resarcimiento de todo daño que se halle en relación de causalidad adecuada con el incumplimiento objetivo, material o antijurídico, más allá de que se pueda imputar o no a nivel estrictamente subjetivo

Para finalizar este punto del análisis, y aún a riesgo de incurrir en una verdad de Perogrullo, es relevante destacar que si bien el Franchising como Sistema Negocial tiene como interesados directos a franquiciantes y franquiciados, hay también interesados indirectos como ser los terceros cocontratantes de la cadena - no consumidores ni usuarios -, esto es, verbigracia entidades financieras, empresas proveedoras de insumos o productos elaborados, agencias publicitarias, locadores de bienes muebles e inmuebles, prestadores de distintos servicios - de seguridad, transporte, limpieza, mantenimiento, etc.-, y otros más. Y los consumidores y usuarios serán, en de-

finitiva, los destinatarios finales de todo este entramado negocial logrado a través de complejas y yuxtapuestas redes contractuales, las que gestadas por el franquiciante, y aceptadas por los franquiciados y los terceros cocontratantes de la cadena ya referidos, tienen por norte la penetración del mercado de oferta masiva de bienes y servicios.

Y ello no debe perderse de mira, en orden a no parcelar y acotar indebidamente el análisis del eventual juego de responsabilidades sobrevinientes en relación a los potenciales consumidores de productos y usuarios de servicios, comercializados a través del Sistema sobre el que se viene discurriendo.

\section{Conceptos claves del negocio.}

Para develar el eventual juego de responsabilidades que los artífices primeros del Sistema de Franchising - franquiciante y franquiciados - pueden llegar a tener ante los consumidores o usuarios que devengan en dañados por la actividad propia de la cadena negocial, se torna imprescindible un mínimo abordaje de conceptos claves del Sistema de Franchising como ser, entre otros, el de poder, control, posición o influencia dominante, dependencia y actividad económica.

El Franchising es, desde adentro y hacia afuera, una "estructura empresarial

28. Ghersi, Carlos A., Modernos conceptos de Responsabilidad Civil, Ediciones Jurídicas Cuyo, Mendoza, 1995, pág. 112. 
de integración"29. Y la forma utilizada para configurarla es piramidal y vertical, vale decir que el poder está concentrado en el vértice superior, y es ejercido desde arriba hacia abajo.

La actuación específica de ese poder se da a través del control que convencionalmente se reserva el franquiciante, en relación a los franquiciados, al momento de otorgar las franquicias individuales. Y si por poder se entiende la aptitud, capacidad o energía que tiene un sujeto para lograr determinados fines ${ }^{30}$, el control sería el instrumento o la técnica patente de la cual se valdría el franquiciante en orden a la consecución de aquéllos ${ }^{31}$, algunos también patentes - v.gr.: defensa de la imagen del Sistema en su conjunto, protección de las variables configurantes del Plan Negocial determinantes del éxito, etc.-, y otros latentes - v.gr.: expectativa de elevada ganancia a riesgo mínimo, evitar a través de los franquiciados agresiones patrimoniales de terceros, etc.--

Al respecto, "dice Champaud que la palabra 'control' se ha convertido en sinónimo de 'sometimiento', pero ............... lo cierto es que hoy se la utiliza en la misma acepción inglesa, es decir, como análogo de 'poder de dominación"'32. Puede entender-

se también al control, genéricamente, como "el acto o el hecho de tener poder o autoridad para guiar o manejar algo con un objetivo determinado" ${ }^{33}$.

La influencia dominante por su parte sería el efecto o consecuencia del ejercicio concreto del referido control por parte del sujeto activo del mismo, en el caso el franquiciante.

Y así como el control, derecho-deber del franquiciante, es causa jurídicamente relevante del deber de responder ante los propios franquiciados, sea por su omisión o por su ejercicio indebido por parte de aquél, también podrá serlo, eventualmente, en relación a los cocontratantes de los franquiciados, incluidos los consumidores y usuarios.

En el marco de lo teórico pueden distinguirse dos tipos básicos de control. Uno denominado control interno, jurídico o de derecho, y otro llamado externo, económico o de hecho ${ }^{34}$. El primero estará dado, fundamentalmente, por la participación del sujeto controlante en el capital social de la controlada, de modo de poder decidir el actuar de esta última a través de la emisión del voto que permita en alguna forma direccionar la voluntad social de la misma,

29. Siginificativamente ese es el título del Capítulo XXVIII de la Obra de Ghersi, Carlos A. y otros, Contratos civiles y comerciales, Astrea, Bs. As., 1994, pág. 25, en donde se incluye el estudio del Franchising, los Joint Ventures, Hipercentros de consumo, y otras estructuras empresariales mercantiles contemporáneas.

30. Conf. Bidart Campos, Germán J., Manual de Derecho Constitucional argentino, Ediar, Bs. As., 1984, pág. 77.

31. Conf. Kleidermacher, Jaime L., Franchising, Abeledo-Perrot, Bs. As., 1995, pág. 201.

32. Conf. Kemelmajer de Carlucci, Aída R., Aproximación al Franchising. Especial referencia al régimen de la responsabilidad civil, en Responsabilidad por daños. Homenaje a Jorge Bustamente Alsina, Abeledo-Perrot, Bs. As., 1990, To II, pág. 289.

33. Santillán, Jorge Mario, Las sociedades controladas y la reforma de la ley 22.903, RDCO-1984-733.

34. Conf. Verón, Alberto V. y Zunino, Jorge O., Reformas al régimen de sociedades comerciales, Astrea, Bs. As., 1984, págs. 37/8; también Santillán, Jorge Mario, Las sociedades controladas y la reforma de la ley 22.903, RDCO-1984-734 y sgles..

Revista da Faculdade de Direito da UFRGS, v. 13, 1997 en caso de tratarse de una persona jurídica mercantil; o por la posibilidad de dirigir al controlado en su accionar merced a la potestad jurídica que la relación le otorga a controlante - verbigracia, relación laboral -, de ser de una persona física la controla da. El segundo estará caracterizado por situaciones fácticas e imposiciones contractuales que, sin afectar la identidad jurídica de la persona controlada, permiten al controlante someterla a sus designios yacentes o subyacentes - "desde afuera" de la misma ${ }^{35}$. "Es dentro de esta situación que enmarca, en muchos aspectos, el ....... Franchising" 36 .

El ejercicio del poder del franquiciante a través del control, cuyo efecto es la influencia dominante, genera en el o los franquiciados una clara situación de dependencia, entendida esta en sentido lato como "subordinación a un poder mayor"37. Es que depender implica genéricamente "estar subordinado, ser condicionado por alguien o algo, quedar al arbitrio de una voluntad, estar atenido a un recurso solo", conforme se describe en las primeras cuatro acepciones del término recogidas por la Real Academia Española ${ }^{38}$; y estas posibles situaciones son coprotagonizadas por los franquiciados, las más de las veces, en virtud del juego propio de los mecanismos que ha ideado y predispuesto el franquiciante,

en pro de la operatividad de la red por él creada.

Subordinación evoca "sujeción a la orden, mando o dominio" de otro ${ }^{39}$. Y si bien en el Franchising formalmente no hay subordinación jurídica directa porque el franquiciante no puede dirigir derechamente la actividad del franquiciado, sino que sólo puede hacerlo indirectamente a través del control - las más de las veces externo y posibilitado por las previsiones convencionales del contrato de franquicia individual -, no hày duda que en la abrumadora mayoría de los casos habrá una clara subordinación técnica y económica de los franquiciados.

La subordinación técnica del franquiciado se dejará evidenciada en los contenidos del Manual de Operaciones, los cuales pueden ser variados por el franquiciante en el curso de la ejecución contractual merced a previsiones expresas contempladas en el contrato de franquicia individual. Esto será más patente en las formas más evolucionadas del Franchising, como ser el business format, pero en menor - pero aún importante - medida estará presente en casi todas las variantes contractuales del negocio - "evidenciándose" de modos distintos -.

La subordinación económica está configurada por un lado por la disparidad

35. Conf. Kemelmajer de Carlucci, Aída R., Aproximación al Franchising. Especial referencia al régimen de la responsabilidad civil, en Responsabilidad por daños. Homenaje a Jorge Bustamente Alsina, Abeledo-Perrot, Bs. As., 1990, T II, pág. 289.

36. Conf. Kemelmajer de Carlucci, Aída R., Aproximación al Franchising. Especial referencia al régimen de la responsabilidad civil, en Responsabilidad por daños. Homenaje a Jorge Bustamente Alsina, Abeledo-Perrot, Bs. As., 1990, T²II, pág. 290.

37. Diccionario de la Lengua Española, XXI Edición, Espasa Calpe, Madrid, 1992, pág. 482.

38. Diccionario de la Lengua Española, XXI Edición, Espasa Calpe, Madrid, 1992, pág. 482.

39. Diccionario de la Lengua Española, XXI Edición, Espasa Calpe, Madrid, 1992, pág. 1355. 
patrimonial que a su favor presenta el franquiciante en relación al franquiciado las más de las veces, lo cual hace que éste aspire a compartir parte del éxito comercial y económico de aquél, mas no a igualarlo, lo cual da al franquiciante un mayor poder negociador a la hora del otorgamiento de la franquicia respectiva. Y por otro lado el negocio en sí está pensado e instrumentado $a b$ initio para que la tasa del ganancia del franquiciante sea siempre mayor en términos absolutos que la de cada franquiciado en particular; es que el franquiciante se aprovecha del éxito de un número de franquiciados normalmente muy superior a "uno", mientras que usualmente el franquiciado contará con el rédito económico de la o las franquicias que le sean otorgadas y que, numéricamente, serán habitualmente menores a las totales de la red $^{40}$.

Desde luego que la indirecta subordinación jurídica, y la evidente subordinación técnica y económica no son configurantes per se de un contrato de trabajo ni de una relación de trabajo en términos del Derecho Laboral. Ello porque el franquiciado será las más de las veces una persona jurídica, no tendrá subordinación jurídica directa, y la actividad que desarro- llará no será en el exclusivo favor, beneficio o interés del franquiciante sino del propio, y el resultado económico que obtenga de la actividad realizada no será "remuneración" sino "ganancia", dado el carácter "asociativo no societario" del contrato de franquicia individual - arg. arts. 21 y 22, Ley de Contrato de Trabajo -. Esto no será óbice para que, verbigracia, en determinados Franchising de conversión no se pueda considerar a los supuestos franquiciados dependientes directos del franquiciante, en caso de que sea comprobable que los contratos de franquicia tuvieron por finalidad licuar potenciales pasivos indemnizatorios provenientes de eventuales acciones laborales o imposibilitar la aplicación de las normas tuitivas propias del Derecho Laboral, en cuyo caso serán nulos - arg. art. 14, Ley de Contrato de Trabajo -; pero esto será normalmente la excepción y no la regla del norte negocial del Sistema.

Paralelamente no puede dejar de considerarse que el Franchising es un Sistema negocial que permite al franquiciante obtener provecho patrimonial a través de la actividad económica directa de terceros, esto es de los franquiciados; pero esta actividad económica de los franquiciados es inducida y organizada por el

40. Ello permite la paulatina absorción de los franquiciados por parte de los franquiciantes; conf. Farina, Juan M., Contratos comerciales modernos, Astrea, 1994, pág. 461, parágrafo 324. Sin embargo Kleidermacher, Jaime L., en Franchising, Abeledo-Perrot, Bs. As., 1995, pág. 203, nola 227, relaliviza la dllerio con la firma Plzza Management, Inc. de San Antonio indicando que la misma regentea 233 ranquicias de Pizza Hut, laco Bell y otras en varios Estados norteamericanos, las Islas Virgenes, España y Puerto Rico, y que en 1990 facturaba casi U\$S 150 millones anuales. Así como Pizza Management Inc. de San Antonio "está detrás" de 233 franquicias en distintos puntos del mundo, Pepsico Inc. "está detrás" de todas las franquicias de Pizza Hut y Taco Bell en distintos puntos del mundo - ver Boroian, Donald D., La ventajas de Franchising, Ediciones Macchi, Bs. As., 1993, pág. 17-, y de seguro que la sola comparación "vis a vis" de la facturación anual de Pepsico como franquiciante de las dos cadenas mencionadas en todo el mundo superará ampliamente la de Pizza Management Inc. como franquiciado de las mismas; sin contar desde luego el producido por otras cadenas de Franchising de las cuales Pepsico también es titular, como Kentucky Fried Chicken, y el de las mismas gaseosas que vende y distribuye universalmente.

Revista da Faculdade de Direito da UFRGS, v. 13, 1997 franquiciante, tal como se advierte por lo que se lleva escrito. Y si bien es cierto que el sistema de economía capitalista - el nuestro - tiene como característica el traslado del riesgo económico "hacia adelante" ${ }^{41}$, no es menos cierto que en orden a determinar eventuales "responsables" debe tenerse también presente que ese mismo sistema económico posibilita mayor obtención de beneficios y acumulación de capital al franquiciante ${ }^{42}$, por lo cual resulta axiológicamente adecuado - y normativamente posible y plausible como se verá - que quien "idea" una actividad económica y la realiza indirectamente a través de terceros, lucrando de ese modo mucho más de lo que podría hacerlo actuando por sí mismo, deba eventualmente responder ante quienes - entre otros - contraten con los franquiciados para posibilitar tal actividad $^{43}$.

A propósito de lo que se está tratando, se ha escrito acertadamente que "quien tiene poder económico tiene responsabili- dad"44, y que ya "puede darse a la luz el verdadero factor de atribución del final del siglo: la actividad económica en si misma" ${ }^{45}$, debiéndose paulatinamente "descubrir el velo" de ella por ser un "gran factor de atribución en la causación de daños" ${ }^{* 6}$, configurándose instrumentalmente a través de "agrupaciones económicas de control"47, como es el caso del Franchising.

\section{Responsabilidad ante los consumidores y usuarios por daños derivados de productos elaborados defectuosos.}

El Franchising, como Sistema negocial de base contractual, puede tener por objeto inmediato real o sustantivo a cosas, entendido ello en el sentido técnico jurídico específico de "objetos materiales susceptibles de tener un valor" - art. 2311, Cód. Civil -. Y tales cosas - pasibles de ser comercializadas por medio de la cadena de distribución instrumentada a través de

41. Conf. Ghersi, Carlos A., Contratos civiles y comerciales, Astrea, Bs. As., 1994, To II, pág. 45.

42. Conf. Ghersi, Carlos A., Contratos civiles y comerciales, Astrea, Bs. As., 1994, To II, pág. 47

43. No me resulta desconocido que se han cuestionado este tipo de razonamientos en un trabajo de Bohmer, Martín Federico, EI análisis del Franchising. Una crisis metodológica, LL-1992-B-1224 y sgtes., los cuales han sido postulados por plumas mucho más autorizadas que la mía como las de Aída R. Kemelmajer de Carlucci, Carloș A. Ghersi y Jorge Mosset Iturraspe entre otros. Respecto a esto no puedo dejar de destacar que siempre el "plano del ser" es el que determina las consecuencias a deducirse del "plano del deber ser", esto es, a diferentes realidades subjetivas u objetivas - v.gr:: económicas -, diferentes consecuencias normativas - v.gr. imputación diferenciada de responsabilidades - . Y ello está consagrado expresamente en muchas disposiciones del Derecho positivo argentino -v.gr.: arts. 520, 521, 888, 889, 902, 904, 905, 907, 909, 954, 1113, párr. 1ํ, 1198, párr. 2ª a $5^{\circ}$, 1204, párr. $2^{\circ}$ a $4^{0}, 2170,2176,3999$ y 4015. Cód. civil, entre otras-, en orden a permitir seguramente la consagración axiologica del valor "equidad".

44. Conf. Kemelmajer de Carlucci, Aída R., Aproximación al Franchising. Especial referencia al régimen de la responsabilidad civil, en Responsabilidad por daños. Homenaje a Jorge Bustamente Alsina, Abeledo-Perrot, Bs. As., 1990, To II, pág. 310.

45. Ghersi, Carlos A., La actividad económica como factor atributivo de responsabilidad, en La Responsabilidad. Homenaje a Isidoro Goldenberg, Abeledo-Perrot, Bs. As., 1995, pág. 352.

46. Ghersi, Carlos A., La actividad económica como factor atributivo de responsabilidad, en La Responsabilidad. Homenaje a Isidoro Goldenberg, Abeledo-Perrot, Bs. As., 1995, pág. 358.

47. Ghersi, Carlos A., Contratos civiles y comerciales, Astrea, Bs. As., 1994, To II, pág. 45.

Revista da Faculdade de Direito da UFRGS, v. 13, 1997 
franquicias comerciales - pueden causar daños a quienes las consuman o utilicen. De allí el abordaje en este acápite de la cuestión relativa a los productos elaborados defectuosos.

Téngase presente que, tratándose del Franchising, los productos serán siempre elaborados por el franquiciado, siguiendo para ello las instrucciones dadas por el franquiciante. Esta es una de las notas distintivas del Franchising en relación a otros Sistemas de distribución comercial, como ser la Agencia, la Distribución - en sentido específico - y la Concesión privada. En estos últimos mecanismos de comercialización ni el agente, ni el distribuidor, ni tampoco el concesionario, fabrican el producto que expenden.

Pues bien, tal como análogamente supo señalar en su día el jurista mexicano Jorge Barrera Graf ${ }^{48}$, así como a comienzos del presente siglo surgió con vigorosa aspiración de autonomía el Derecho del Trabajo como capítulo del Derecho Social, estando próximo a finalizar el mismo se destaca en igual sentido el Derecho del consumidor y del usuario, que tiene por diana de estudio a la "relación de consumo o uso", como categoría o correlato paralelo o equivalente de la "relación de trabajo" propia del Derecho laboral.

En virtud de su trascendencia tal "relación de consumo" fue receptada normativamente en la Argentina por la llamada Ley de Defensa del Consumidor №
24.240 primero - en adelante LDC - , y por la propia Ley Fundamental después - art. 42, Constitución Nacional -

La necesidad del abordaje de la referida "relación de consumo" surge como conseriada y a gran escala en el ámbito de la industria, con motivo, fundamentalmente, de la implementación generalizada del sistema fordista primero, y posfordista después ${ }^{49}$.

Con la finalidad de colocar en el mercado de consumo los bienes producidos se induce a la adquisición masiva de los mismos a través de la "publicidad comercial", la que por cierto no se distingue en la actualidad de la otrora denominada "propaganda", dado que más que "hacer saber" se busca "convencer". De allí que aún anvirtualmente derogó, en el ámbito del Derecho del consumidor y del usuario, los arts. 1148 del Cód.Civil y 454 del Cód. de Comercio, haciendo que la oferta a persona indeterminada al igual que lo "anunciado" publicitariamente sea vinculante; conf. arts. 7 y 8 de LDC y del Dto. 1798/94-, plumas autorizadas hayan postulado que "la publicidad inductiva integra la relación contractual"so.

Inducida o despertada masivamente la necesidad del consumo o del uso, se incrementa geométricamente y en un espiral ascendente la demanda de bienes y servicios. Con la finalidad de satisfacer tal secuencia de la posibilidad de producción tes de la existencia misma de la LDC - que

48. La responsabilidad del producto en el derecho mexicano, Revista de Derecho Comercial y de las Obligaciones, año 11, № 64, Agosto '78, pág. 702.

49. Conf. ello en Ghersi, Carlos A., Contratos civiles y comerciales, Astrea, Bs. As., 1994, To I, págs. 6 a 21.

50. Conf. Ghersi, Carlos A., La publicidad inductiva integra la relación contractual, JA-1989-II-939.

Revista da Faculdade de Direito da UFRGS, v. 13, 1997 demanda, aumentadora en términos reales del lucro posible del productor o prestador se incrementa el ritmo de la producción. Y el efecto colateral no deseable, pero verificable, es el incremento proporcional de los defectos de fabricación e implementación, lo que introduce en la sociedad global ma yores riesgos para los destinatarios finales de los bienes o servicios, esto es los consumidores o usuarios.

Al respecto, la autorizada pluma de Jorge Bustamante Alsina - quien fue segu ramente el primero en ocuparse en Argentina de estos temas - ha escrito que "lo expuesto aparece actualmente como un riesgo social que se acrecienta, dada la fa bricación en serie de objetos de todo tipo destinados al uso y al consumo, favorecidos por una tecnología que facilita la producción en masa y que, por ello mismo, no obstante las medidas de control y seguridad que se adopten, arrojan un alto porcentaje de productos que entran al proceso de comercialización en deficientes y peligrosas condiciones" 51 .

Se ha dicho también que "todos estos factores han creado una situación de vulnerabilidad del consumidor, quien se ha visto enfrentado al poderío económico y jurídico de los productores, que lo coloca en una condición similar a la del proletario creado por el capitalismo industrial del siglo XIX, y que han llevado a la necesidad a nivel mundial de incluir, en sus ordenamientos legales, normas tendientes

a proteger al consumidor frente a los daños ocasionados por productos elaborados". Naturalmente que "han acelerado el proceso de búsqueda de soluciones jurídicas idóneas, los abusos registrados en la elaboración de productos de uso y consumo masivo, desde los productos comestibles en mal estado (recordamos en este punto la intoxicación masiva de 25.000 personas en España provocada por la ingestión del aceite de colza), los productos farmacéuticos (como el resonado caso de la droga talidomida, el producto medicinal Softenol, causante del nacimiento de niños con malformaciones), etc. Más recientemente, han ocurrido algunos episodios que han conmocionado a nuestra sociedad en casos de diversos productos comestibles en mal estado, vinos adulterados, etc., todos con dramáticas consecuencias" 52

Es bueno remarcar que en lo atinente a los productos elaborados, se focalizará el abordaje en orden a establecer el mecanismo jurídico posible de resarcimiento de daños del que podrán eventualmente echar mano los consumidores o usuarios, ante perjuicios padecidos en su persona o en el resto de sus bienes, derivados de defectos intrínsecos o de presentación de productos manufacturados que hayan sido a su turno "objeto inmediato real o sustantivo" de contratación de consumo o uso.

Distinta cuestión es la relativa al daño que potencialmente sufra la cosa misma objeto de tal contratación en virtud de

51. Bustamante Alsina, Jorge, Responsabilidad civil por productos elaborados en el Derecho Civil argentino, LL-143-870.

52. Weingarten, Celia, Responsabilidad por productos elaborados, en Ghersi y otros, Derechos y responsabilidades de las empresas y consumidores, Organización Mora, Bs. As., 1994, p. 112.

Revista da Faculdade de Direito da UFRGS, v. 13, 1997 
su defecto intrínseco que la haga impropia para su destino, tema que no será analizado en este trabajo.

Ahora bien, mucho antes del auge de la Semiótica y de la Filosofía Analítica, en su día supo decir Francois Arouet de Voltaire que "si queréis conversar conmigo, definid primero vuestros términos", y sobre el punto mucho ha trabajado en la Ciencia de Derecho el maestro Genaro Carrió quien alertara acerca de la ambiguedad, la vaguedad y la textura abierta como defectos típicos y abarcadores de los lenguajes natural y normativo. Es conveniente especificar entonces, que por "producto elaborado" se entiende toda aquella cosa que es el resultado de la transformación de otras cosas por la actividad del hombre aplicada a las mismas ${ }^{53}$. Por su parte Farina propone como concepto que "por producto elaborado se entiende toda cosa mueble, natural o industrial, destinada a la comercialización, en cuyo proceso de creación, transformación o desarrollo, así como en la preparación para su consumo o uso haya intervenido la actividad humana, sin olvidar que también cabe ubicar dentro de este concepto a los productos naturales, pues requieren de la intervención del hombre, tanto en lo relativo a su desarrollo (p. ej., la aplicación de fertilizantes, etc.) como a su conservación, fraccionamiento o envase" 54 .

En otros términos, y teniendo presente lo normado en la LDC, puede

53. Conf. Bustamante Alsina, Jorge, Responsabilidad civil por productos elaborados en el Derecho Civil argentino, LL-143-870.

54. Farina, Juan M., Contratos comerciales modernos, Astrea, Bs. As., 1994, p. 198.

55. Agoglia, Boragina y Meza, Responsabilidad civil por daños causados por productos defectuosos, JA-1990-I-742.

56. Farina, Juan M., Contratos comerciales modernos, Astrea, Bs. As., 1994, p. 199.

Revista da Faculdade de Direito da UFRGS, v. 13, 1997 nado Derecho de Daños y una de las cuestiones de mayor importancia dentro del campo de los derechos del consumidor"s?. No por casualidad ello ha sido expresa y primeramente contemplado, entre otros derechos, en el art. 42 de la reformada $\mathrm{CN}$ de Argentina de 1994, en donde puede leerse que "los consumidores y usuarios de bienes y servicios tienen derecho, en la relación de consumo, a la protección de su salud seguridad ..................." y otros derechos más, que a continuación de los dos señalado primeramente son enumerados a título enunciativo.

Esto último había sido receptado pre viamente ya en el art. 5o de la LDC, en donde se prescribe que "las cosas y servi cios deben ser suministrados o prestados en forma tal que, utilizados en condiciones previsibles o normales de uso, no presen ten peligro alguno para la salud o integridad física de los consumidores o usuarios". $Y$ "ello es natural, por cuanto la protección de la salud y la seguridad de las personas constituye el piso mínimo de defensa de las mismas, que permite así gozar de los demás derechos ${ }^{\prime \prime 8}$, entre los cuales se encuentra, naturalmente, el de propiedad.

En consecuencia, menoscabada que sea la salud, seguridad o patrimonio de consumidores y usuarios, por el uso o consumo de productos elaborados defectuosos, debe acudirse a mecanismos normativos que posibiliten el resarcimiento de los daños padecidos.

\footnotetext{
57. Andomo Luis O, Responsabilad por daño a batudo
}

No es ocioso destacar que pueden darse diversos supuestos generadores del daño por productos elaborados, no sólo debido a un vicio intrínseco de éstos, sino también por información errónea o instrucciones deficientes sobre su modo de empleo. Tales supuestos pueden consistir, siguiendo a Farina, en : a) daños provocados por deficiencias en proyectos, planos o fórmulas químicas del producto, b) vicios de fabricación o de manipulación del producto, c) vicios derivados de una defectuosa conservación del producto hasta su entrega al adquirente, d) deficiente información al consumidor o usuario y e) daños derivados de una publicidad imprudente ${ }^{59}$.

En orden a precisar las posibilidades normativas de reparación con que potencialmente contarían los consumidores o usuarios eventualmente dañados merced al giro propio del Sistema de Franchisisng, se deben distinguir básicamente dos hipótesis posibles: a) damnificado por producto defectuoso que adquirió u obtuvo el mismo en forma directa del franquiciado, $\mathrm{y} b$ ) damnificado no propietario ni guardián del producto elaborado (efectivo consumidor final).

Así, tratándose de una relación directa entre el franquiciado - fabricante del producto elaborado - y el consumidor o usuario que consumió o utilizó el mismo, la base del eventual deber de resarcir del primero nombrado será ciertamente contractual. Pero dado que hay una implícita

Andorno, Luis O., Respor
Bs. As., 1995, p. 479 .

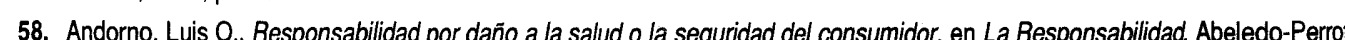
Bs. As., 1995, p. 481.

59. Farina, Juan M., Contratos comerciales modernos, Astrea, Bs. As., 1994, p. 201.

Revista da Faculdade de Direito da UFRGS, v. 13, 1997 
obligación de resultado o fines en cabeza del franquiciado que hace las veces de proveedor directo, consistente en una garan tía de inocuidad del bien a ser consumido o utilizado y en la seguridad de que el mismo no irrogará en ningún caso daños persona les o patrimoniales a quien lo adquirió - más allá de que concretamente deba. ser apto para su destino específico -, tal responsabi lidad contractual será objetiva, dado que el franquiciado no podrá eximirse de respon der probando su "no culpa" - de allí que en este caso no pueda predicarse ni presumirse imputabilidad subjetiva alguna en relación al mismo $-{ }^{60}$. Y la plataforma normativa básica de apoyo a la pretensión resarcitoria estaría dada por los arts. 1137 y 1197 de Cód. Civil en virtud del incumplimiento objetivo del "pacta sunt servanda", debiendo asimismo tenerse presente que "los contratos - de consumo o uso en la hipótesis deben celebrarse, interpretarse y ejecutarse de buena fe y de acuerdo con lo que verosímilmente las partes entendieron o pudieron entender - el producto elaborado no depararía consecuencias nocivas para la persona o bienes de quien lo utilizace o con sumiese - obrando con cuidado y previsión" - art. 1198, párr. primero, Cód. Civil-, obligando los actos jurídicos bilaterales no sólo a lo patente o evidente - verbigracia, aptitud del producto para el uso o consumo previsto- sino también a lo latente, subyacente o virtualmente abarcado por la con- vención - arg. arts. 1198, párr., primero y 1198 derogado, Cód. Civil - ${ }^{61}$.

La extensión del resarcimiento será la determinada como "metro patrón" en los arts. 901 y ss. del Cód. Civil - con especial ponderación del 902 -, en donde se pondera la "previsibilidad en abstracto" propia de la relación de causalidad, quedando lo prescripto en los arts. 520 y 521 del Cód. Civil sólo para ser aplicado al "estrecho campo" de la responsabilidad contractual subjetiva que atiende a la "previsibilidad en concreto" - arg. art. 512 Cód. Civil - en caso de obligaciones de medios, siendo entonces plenamente resarcibles todos los daños padecidos que tengan relación de causalidad adecuada con el incumplimiento objetivo o material - en cuanto al resultado "esperado" y "esperable" - del franquiciado fabricante ${ }^{62}$.

Las causas de exoneración de las que podrá valerse el franquiciado elaborador serán necesariamente "ajenas" y deberán atender a quebrar, desplazar o concausar la relación de causalidad - y no a obstar a un factor subjetivo de atribución -, esto es caso fortuito o fuerza mayor, culpa de la víctima o de un tercero por quien no deba responder - arg. arts. 513, 514, 1113, párr. segundo, in fine, Cód. Civil ${ }^{63}$.

Asimismo, el consumidor o usuario dañado podrá accionar contra el franquiciante - que es quien convencio-

60. Conf. Vázquez Ferreyra, Roberto A., La responsabilidad contractual objetiva, LL-1988-B-998 y ss. y Bueres, Alberto J., Responsabilidad contractual objetiva, JA-1989-II-964 y ss.

61. Conf. Mosset Iturraspe, Jorge, Contratos, Ediar, Bs. As., 1984, p. 262.

62. Conf. Agoglia, Boragina y Meza, La extensión del resarcimiento en la responsabilidad objetiva, JA-1990-II-735 y ss.

63. Conf. todos los autores y obras citados en este acápite y, asimismo, Ghersi, Carlos A., La responsabilidad civil sin culpa en el Proyecto de Unificación civil y comercial, suplemento diario de LL, 15-02-88, p. 2.

Revista da Faculdade de Direito da UFRGS, v. 13, 1997 nalmente impone el modo de elaboración de los productos del caso y fija sus estándares de calidad - con base extracontractual y apoyo normativo en el art. 1113, párr. primero, Cód. Civil, dado que el organizados de la red "se sirve" de los productos - "cosas" - que manufactura el franquiciado para lucrar indirectamente y, por lo tanto, deberá responder en virtud del factor de atribución objetivo derivado del riesgo de su "actividad económica" realizada a través del giro de los franquiciados - en caso de irrogarse, merced a tales bienes, daños a terceros ${ }^{64}$. $Y$ es bueno reparar en que el antecedente del riesgo de actividad económica como factor objetivo de imputabilidad, no es sino la aplicación posmoderna de la máxima contenida en la Institutas de Justiniano: $u b i$ emolumentum, ibi onus, es decir, allí donde está el beneficio, debe estar la carga ${ }^{65}$.

Las pautas de extensión del resarcimiento y de exoneración son idénticas a las descriptas para el franquiciado.

El vendedor del producto defectuoso y su elaborador serán legitimados pasivos conjuntos y "concurrentemente" obligados por el todo del daño hacia el consumidor o usuario perjudicado.-

Es que por un lado al presente ninguna norma positiva impone expresamente la solidaridad entre los primeros nombrados en orden a la eventual reparación - distinta sería la situación si el P.E.N. no hubiese "observado" el art. 40 de la LDC, merced

al Dto. 2089/93 -; y la misma sólo puede tener base legal o convencional, y esto último por hipótesis de realidad tampoco se dá -arg. art. 701 del Cód. Civil -. Sólo el segundo párrafo del art. 1109 del Cód. Civil permitiría implícitamente predicar responsabilidad solidaria entre el fabricante y el vendedor de esta hipótesis, pero ello no resulta tan "expreso" como sería deseable arg. art. 701 Cód. Civil - y, asimismo, sería en cierto modo óbice para ello la decimonónica valla normativa del art. 1107 Cód. Civil - en relación al vendedor -.

Pero por otro lado es imperioso considerar que si el damnificado puede accionar contra el vendedor o contra el fabricante, en virtud de causas fuente distintas pero debido a un mismo daño pade. cido, teniendo la expectativa de resarcirse indistintamente de cualquiera de ellos el ciento por ciento del perjuicio por hipótesis sufrido -no más del ciento por ciento entre ambos en virtud del principio del enriquecimiento indebido o sin causa, desde luego, dado que si bien las causas fuente son distintas el daño soportado fue uno solo -, no hay obstáculo alguno para que accione conjunta y simultáneamente contra ambos, y que siendo ambos condenados a resarcir pueda cobrarse indistintamente de cualquiera de ellos el todo de su acreencia, o que eventualmente cada uno de los agentes causales participe en el resarcimiento conforme ellos mismos hayan acordado. Está claro entonces que estamos en presencia de una explícita o patente "obligación

64. Conf. Ghersi, Carlos A., La actividad económica como factor atributivo de responsabilidad, en La Responsabilidad, AbeledoPerrot, Bs. As., 1995, p. 351 y ss..

65. Conf. Zannoni, Eduardo A., El daño en la responsabilidad civil, Astrea, Bs. As., 1982, pág. 30. 
concurrente de hecho" y, en consecuencia, de una implícita o latente "obligación concurrente de derecho".

Es que en el Derecho Positivo argentino, en el plano de las obligaciones conjuntas, además de las obligaciones simplemente mancomunadas y solidarias perfectas, se encuentran las denominadas obligaciones indistintas, conexas, concurrentes, solidarias imperfectas o "in solidum" - en ocasiones expresamente previstas, y en otras virtualmente contenidas $y$ verificables-, que determinan que cada uno de los obligados deba responder por el todo ante el damnificado, pudiéndose en el lado pasivo y en lo interno de la relación bipolar obligatoria accionarse luego recursoriamente o de regreso entre sí-verbigracia, franquiciante y franquiciado que son deudores concurrentes- para resarcirse a su vez de lo oblado indebidamente en exceso, hasta por el ciento por ciento de lo por hipótesis pagado, - arg. arts. 689 , inc. $2^{\circ}, 716,717,768$, inc. $2^{\circ}$, 771 , inc. 3으 1113 y 1123 todos del Código Civil- ${ }^{66}$.

Si el dañado no es dueño o guardián del producto defectuoso al tiempo en que padece el perjuicio, está legitimado para accionar extracontractualmente contra el dueño o guardián de la cosa al momento de producirse el daño en virtud del art. 1113, párr. 2º, Cód. Civil - atribución objetiva por su calidad de dueño o guardián -, y contra el fabricante del bien - franquiciado - y el franquiciante - instructor de su elaboración - merced al art. 1113, párr. $1^{\circ}$, Cód. Civil atribución objetiva por la actividad eco-

nómica realizada a través de la cosa defectuosa -, teniendo la extensión de la reparación, la obligación de "concurrir" al pago del resarcimiento y las causales eximentes de responsabilidad, idénticas características a las que se vienen predicando para el otro supuesto ya contemplado antecedentemente. La señalada actividad económica del franquiciado será directa, y la del franquiciante indirecta - a través de el o los franquiciados -. Pero ello no modifica las soluciones normativas dogmáticas propiciadas en modo alguno, dado que en el artículo citado no se distingue entre la inmediatez o mediatez del aprovechamiento de las cosas para la imposición de la eventual reparación de los daños causados. Y donde no distingue la ley no debe hacerlo el intérprete, a no ser que haya motivos para ello; y en el caso no se advierten - ni en el plano de lo fáctico, ni en el de lo valorativo -.

Merece destacarse por último, pese a ser casi una verdad de Perogrullo, que la legitimación activa del sujeto dañado en esta hipótesis viene dada por su calidad de efectivo consumidor o usuario final, que lo transformó en definitiva en damnificado.

Desde luego que así como quien devenga en perjudicado por la utilización o consumo de un producto elaborado defectuoso puede accionar contra quien lo fabricó -franquiciado-, lo ideó e instruyó para su elaboración -franquiciante - e, inclusive, contra quien era su dueño o guardián al momento del evento dañoso - verbigracia un amigo de la víctima -, también son potenciales legitimados pasivos de tal preten-

66. Conf. Kemelmajer de Carlucci, Aida, Responsabilidad del Estado, en Estudios en homenaje al Dr. Guillermo Borda, Bs. As., La Ley, 1985, p. 230 y Andorno, Luis O., La responsabilidad civil y la obligación «in solidum», JA-Doctrina-1972-429 y ss..

Revista da Faculdade de Direito da UFRGS, v. 13, 1997 sión reparadora el transportista, el publicista y el Estado mismo -sea Nacional, Provincial o Municipal-. El transportista para el caso, verbigracia, de que hubiese interrumpido la cadena de frío o no hubiese observado normas técnicas vigentes para el traslado de los productos tendientes a evitar inmisiones nocivas o posibles contaminaciones. El publicista en el supuesto de que hubiese promocionado incorrectamente el producto, incurriendo en abuso, engaño $u$ omisión, según el caso. Y el Estado siempre deberá responder, para la hipótesis de que se acredite relación causal adecuada entre la ausencia o deficiencia del control o ejercicio del poder de policía y el resultado lesivo generado por el producto, lo cual no es excluyente de la responsabilidad de el o los funcionarios públicos involucrados en la cuestión -arg. arts. 33, 43, 1112, 1113, 1122 y ccdtes. del Cód. Civil-. Todo esto último así fue decidido y recomendado, por ejemplo, en las Primeras Jornadas de Responsabilidad Civil por Productos Farmacéuticos y Medicinales celebradas en Morón, Provincia de Buenos Aires, Argentina, en el año 1987, y ello concuerda con una de las tendencias contemporáneas del Derecho de Daños, cual es la ampliación de la legitimación pasiva, de modo de brindar al damnificado mayores posibilidades de resarcimiento efectivo.

\section{Responsabilidad ante los usuarios derivada de la prestación de servicios defectuosos.}

Los servicios no se consumen; se utilizan. Ello porque los mismos no se extin- guen o acaban con su uso, dado que no son efímeros por naturaleza, esto es no son susceptibles de ser agotados por su utilización, aunque sí pueda consumirse una porción de la manifestación del servicio, como puede ser el caso del fluido gaseoso, la energía eléctrica, etc. De allí que los que reciben servicios de terceros sean propiamente usuarios, más que consumidores. También en el caso de algunos productos elaborados no es correcto predicar consumo sino uso de los mismos y, consecuentemente, quien los utiliza será usuario y no consumidor los contestadores telefónicos y las computadoras no se consumen; los productos farmacéuticos y las comidas rápidas sí-.

A través del Franchising también pueden distribuirse servicios. Tal sería el caso de una cadena de Hotelería, de unas rutinas de ejercicios ideadas para determinados fines anatómicos, de un modo específico de efectuar Consultoría profesional, de salones de belleza, lavaderos de automóviles, educación diferencial, sistemas de tratamiento de aguas, oficinas de empleo y contrataciones temporales, y de tantas otras posibilidades que de seguro se le ocurrirán al lector ${ }^{6}$,

En cuanto a este tópico, prevalece, para la configuración de la responsabilidad derivada de la hipotética prestación defectuosa de tales servicios, la figura de la sub. ordinación que tiene el franquiciado respecto del franquiciante, resultante de la influencia dominante que se determina a través del control por el cual el franquiciante ejerce su poder sobre todo

67. Conf. Kleidermacher, Jaime L., Franchising, Abeledo-Perrot, Bs. As., 1995, págs. 88/9. 
adherente a la red negocial. $Y$ esto ya fue analizado suficientemente más arriba - en el parágrafo $2-$, por lo cual a todo ello se remite al lector, brevitatis causae.

Para el supuesto de que el servicio fuese dañoso en origen, esto es en la concepción misma que de él haya hecho el franquiciante, la responsabilidad de éste será palmaria, por cuanto tal servicio ideado para prestar a terceros es de su autoría. $Y$ en caso de que la lesión a los intereses del usuario devenga de la incorrecta prestación del servicio por parte del franquiciado, el franquiciante también será responsable porque eventualmente habrá faltado al ejercicio regular y adecuado de su derecho-deber esencial, esto es el control de lo actuado por el propio franquiciado.

Así, como entre franquiciante y franquiciado habrá subordinación técnica y económica evidente, y además subordinación jurídica indirecta lograda a través del control, se dan los extremos para predicar "dependencia" del segundo respecto del primero en la órbita del Derecho Privado Patrimonial. Es que en tal ámbito, "la relación de dependencia o subordinación se manifiesta a través del derecho de dar órdenes o instrucciones acerca de la manera como deben cumplirse las funciones. Ese derecho de dar órdenes es el que origina la autoridad y la subordinación. Lo tipificante es el derecho, aunque de hecho no se haya dado ninguna orden o el comitente no haya ejercido su autoridad. Es decir, hay que atenerse a la existencia de la autoridad, no al

ejercicio de ella. En esta línea se ha dicho que la dependencia se traduce en la facultad de dirigir, vigilar, intervenir en la conducta de otro; se requiere dos personas ligadas por una relación jerárquica: uno con derecho a mandar y otro con deber de obedecer. Pero por sí sola la facultad de dar órdenes no es suficiente para la configuración de la relación de dependencia ............. . Para que la subordinación haga nacer la calidad de comitente, es imprescindible que la función encomendada satisfaga el interés de quien da las órdenes"68.

Nótese que "si se entiende por dependencia el derecho de dar órdenes o instrucciones acerca de la manera como deben cumplirse las funciones; si se traduce en la facultad de dirigir, controlar, vigilar, intervenir en la conducta de otro, etcétera, no hay dudas que, normalmente, estos recaudos se dan en el 'franchising"'69. Y por ello es que debe responder el franquiciante en forma concurrente con el franquiciado ante eventuales daños que los servicios del caso irroguen a sus usuarios.

La base normativa de lo anterior está también en la primera parte del art. 1113 del Cód. Civil, en donde puede leerse que "la obligación del que ha causado un daño se extiende a los daños que causaren los que están bajo su dependencia.......", y dado que la relación del usuario dañado con el franquiciante será extracontractual, el art. 1107 del mismo Cód. Civil no será valla para la aplicación de la primera norma citada respecto del último nombrado, que tiene por

6. Kemelmajer de Carlucci, Aída, comentario al art. 1113 del Cód. Civil argentino, en Belluscio-Zannoni, Código Civil y leyes complementarias, comentado, anotado y concordado, Astrea, Bs. As., 1984, T 5, pág. 434.

69. Kemelmajer de Carlucci, Aída, Daños causados por los dependientes, Bs. As., pág. 87. "dependiente" - con los alcances expresados - al franquiciado.

En lo que hace al franquiciado, la parte del art. 1113 del Cód. Civil antes transcripta será de potencial aplicación sólo sí el usuario padece daños encuadrables también penalmente, como sería el caso de las lesiones - arg. arts. 1107, Cód. Civil, in fine, y 94 del Cód. Penal -. En los restantes supuestos, responderá con base en los arts. 1137, 1197 y 1198, primer párrafo, del Cód. Civil, por haber violado la implícita obligación de resultado o fines de su débito convencional, consistente en la garantía de inocuidad del servicio a ser utilizado y en la seguridad de que el mismo no irrogará en ningún caso daños personales o patrimoniales a quien lo requirió - más allá de que concretamente deba ser apto para su destino específico -, tal como ya se analizó en el parágrafo anterior para el caso de los productos elaborados defectuosos.

\section{Responsabilidad ante los consumidores y usuarios por eventuales daños derivados de los riesgos del desarrollo.}

Esta cuestión refiere a los daños que no pudieron ser previstos por el responsable - verbigracia franquiciante y franquiciado - al tiempo en que la actividad fue ejercida o la cosa riesgosa o viciosa fue puesta en circulación merced a su introducción en el mercado de uso o consumo masivo, debido a que los conocimientos técnicos del momento y el estado de la Cien-

70. Conf. Monti, Eduardo J., Responsabilidad civil de productos farmacéuticos, El Derecho, 121, págs. 820 a 826 . cia impedían advertir su peligrosidad. Y si bien el tema adquiere relevancia genérica en materia de productos elaborados, tiene trascendencia específica en cuanto a productos farmacéuticos y medicinales - los cuales pueden ser elaborados y comercializados a través del Franchising -, al punto de que los desarrollos de Doctrina científica en este tópico se inician mayormente a partir de sucesos dañosos producidos en virtud de efectos perjudiciales acaecidos diferidamente en el tiempo, derivados de la ingesta de medicamentos o la utilización de especialidades farmacéuticas.

A mero título ejemplificador, destácanse en los EE.UU. casos como el de la droga MER-29, usada para la reducción del colesterol en sangre, que fue retirada de la venta en 1962 porque producía lesiones a la vista. O el conmovedor caso del DES, iniciales de la síntesis de una hormona femenina llamada diethylistigesterol, que hacía las veces de sustancia antiabortiva o progestacional, producto que lanzado al mercado en 1941 fue prohibido por la FDA recién treinta años más tarde, luego de confirmarse que un elevado porcentaje de las hijas de quienes habían ingerido dicho medicamento durante el embarazo, desarrollaban un tipo de cáncer de cuello de útero hacia la pubertad, esto es aproximadamente doce años más tarde de haber sido alumbradas $^{70}$. Precisamente uno de estos casos que dió lugar al proceso caratulado "Sindel c/ Laboratorios Abbot", habilitó a que la Corte de California en 1977 aplicase una nueva y pragmática teoría que se nominó del market share o de participación en el 
mercado $^{71}$, que es una de las actuales variantes posibles en la órbita de la Responsabilidad colectiva, esto es la de un sujeto indeterminado dentro de un grupo determinado, lo cual evoca ciertamente el título de la monografía de quien primero sistematizó la cuestión a nivel doctrinal, el francés Aberkane en 1958, de seguro debido a la afición de los galos por el deporte de la cacería.

También los consumidores franceses fueron víctimas de esta especie de los riesgos del desarrollo, a través de un producto medicinal denominado Stalinon, que prescripto para combatir ciertas enfermedades de la piel desde 1953, produjo la muerte e invalidez de centenares de personas.

Difícil es no traer a cuento el tristemente célebre caso alemán generado por el fármaco llamado Contergan-Thalidomida, que indicado en su día como analgésico para las embarazadas, arrojó un resultado gravoso para más de 4.000 descendientes afectados, que tuvieron malformaciones físicas a consecuencia de la monodroga que contenía el referido medicamento, comercializado en algunos otros países bajo la marca de Softenol.

Se apreciará, en base a los anteriores ejemplos, que no es de extrañar entonces que haya sido la industria farmacéutica y la de especialidades medicinales la que casi monopolizara los desvelos de la Doctrina

científica, y aún de los legisladores, en orden a brindar un marco regulatorio de la especie de riesgos del desarrollo sobre la que se viene discurriendo.

En Argentina en particular, ello fue tratado en varios eventos científicos a partir de las "VIII Jornadas Nacionales de Derecho Civil" realizadas en La Plata en 1981. La cuestión también fue abordada en las "IV Jornadas Rioplatenses de Derecho" celebradas en Punta del este en 1986, al igual que en las "I Jornadas sobre responsabilidad por productos farmacéuticos y medicinales" desarrolladas en Morón en 1987. De gran trascendencia fueron las conclusiones a las que se arribó en la cuestión en las "Jornadas Marplatenses de Responsabilidad Civil y Seguros", que transcurrieron en la Ciudad atlántica en 1989. Allí, con la disidencia de Ricardo Lorenzetti y de Lombardi, se aprobó y recomendó, con el apoyo de la opinión mayoritaria de la Comisión redactora del caso, que "en los casos de lanzamiento al mercado masivo de consumo de productos cuya nocividad no era conocida al momento de su puesta en circulación, pero que nuevas comprobaciones científicas o técnicas ponen de manifiesto, cabe responsabilizar al productor, que debe garantizar a los consumidores la inocuidad de los bienes que introduce en la comunidad. El profesional de la salud será responsable cuando la nocividad del medicamento prescripto era conocida o cognoscible, e igualmente lo indicó"

71. Conf. Kemelmajer de Carlucci, Aida, La responsabilidad colectiva y los daños producidos por los productos elaborados, Revista Jurídica de San Isidro, № 24, 1988, págs. 133 a 139 .

72. Conf. Goldenberg, Isidoro H. y López Cabana, Roberto M., Los riesgos del desarrollo en la responsabilidad del proveedor profesional de productos, Jurisprudencia Argentina, 1990-I, págs. 917 a 920.

Revista da Faculdade de Direito da UFRGS, v. 13, 1997
Así, la Doctrina científica que comenzó dividida en en la VIII Jornadas nacionales de 1981, y se fue pronunciando en el sentido de responsabilizar al elaborador por los riesgos del desarrollo tanto en las Jornadas Rioplatenses de 1986 como en las de Morón de 1987, terminó por inclinarse mayoritariamente en tal dirección en las Jornadas Marplatensese de $1989^{73}$.

Pero de ceñirnos a un estricto crite rio dogmático, parecería que en la Argentina, al menos por ahora y en la órbita del Derecho Civil y en la del Derecho del Consumo y del Uso, no resulta posible normativamente colocar a cargo del elaborador esta especie de los riesgos del desarrollo o, lo que es lo mismo, no considerar a los mismos como caso fortuito ajeno a la actividad del empresario ${ }^{74}$.

Es que si bien en materia de medica mentos en especial tanto el recobrar la salud como la seguridad en la ingesta del producto conforman lo que autorizada Doctrina denomina "móviles causalizados" en la órbita de la contratación privada - verbigracia, Alberto J. Bueres -, y por ello están incorporados latentemente en los débitos convencionales, no es menos cierto que la realción de causalidad, que es la piedra de toque de la extensión del resarcimiento o, lo que es lo mismo, la que determina los límites de la reparación civil -por parafrasear a Atilio Alterini-, impide que se imponga a quien debe responder objetivamente por los resultados dañosos de su actividad económica peligrosa, el resarcir

las consecuencias mediatas imprevistas o imprevisibles o de tercer grado, denominadas casuales en el art. 905 del Cód. Civil. Y la nocividad no conocida en virtud del estado de la Ciencia al tiempo de elaborar e introducir al mercado masivo determinado producto es de por sí algo objetivamente imprevisible para el industrial. Y lo que no ha podido preverse es configurante del casus, y fractura el nexo causal adecuado que debe existir entre en incumplimiento material y el daño provocado para que éste sea resarcible, tal como se dispone genéricamente en los arts. 513 y 514 del Cód. Civil.

Por las consideraciones vertidas es que entiendo que ni franquiciante ni franquiciado deben responder por este tipo de riesgos del desarrollo ante los consumidores o usuarios que padezcan daños derivados de los mismos.

Parecería excesivo aplicar una teoría ultraobjetiva como la de Rumelin, traida a cuento en Argentina como variante de la teoría de la causa adecuada por Alfredo Orgaz, Sebastián Soler, Llambías, Cazeaux, Trigo Represas, Atilio Alterini, López Cabana y algunos otros, por la que se propicia que el Juzgador debe apreciar la adecuación de la acción al resultado teniendo en consideración todas las circunstancias existentes al momento de la acción, fuesen ya conocidas en ese momento o solamente después - por lo cual quizá llevase razón Llambías que entendía que bien vista esta teoría coincidía con la de la causa efeiciente

73. Conf. Goldenberg, Isidoro H. y López Cabana, Roberto M., Los riesgos del desarrollo en la responsabilidad del proveedor profesional de productos, Jurisprudencia Argentina, 1990-l, págs. 917 a 920.

74. Conf. Lorenzetti, Ricardo L., Medicamentos y responsabilidad civil, La Ley 1989-D, págs. 960 a 968. 
-, habida cuenta de que hay opinión pacífica en el sentido que la extensión de la reparación en materia de responsabilidad objetiva es idéntica a la que rige en la órbita de los cuasidelitos, fundamentalmente porque el art. 1113 del Cód. Civil está inserto dentro de un Título que trata, significativamente, acerca "De las obligaciones que nacen de los hechos ilicitos que no son delitos".

Curiosamente, legislaciones comunitarias como la de la otrora CEE, actual UE, comenzaron por imponer en la Directiva № 893 de 1976 que el fabricante respondía por los riesgos del desarrollo, para luego, a nueve años vista, desresponsabilizar al productor de las consecuencias dañosas derivadas de tales riesgos, merced a la Directiva № 374 del año 1985

Lo descripto, sin embargo, no implica que particularmente los elaboradores de especialidades farmacéuticas o medicinales no deban seguir de cerca la evolución de los efectos colaterales o secundarios de los productos elaborados. Por el contrario, la Ley de Medicamentos argentina prevé la adecuación periódica de la farmacopea de acuerdo con el progreso de la ciencia, lo que implica que los industriales del rubro tienen un débito con causa fuente legal que les impone eventualmente el deber de advertir la lesividad diferidamente detectada de determinado producto al igual que su retiro del mercado de darse el caso. $Y$ de no cumplirse con ello, se deberá resarcir a los perjudicados por tales supuestas omisiones, dado que, por otra parte, "cuando mayor sea el deber de obrar con prudencia y pleno conocimiento de las cosas, mayor será la obligación que resulte de las consecuencias posibles de los hechos", tal como reza en el art. 902 del Cód. Civil.

Ítem más, en el art. 4º del Dto. 1798/ 94, reglamentario de la LDC, se establece que los proveedores de cosas o servicios están obligados a comunicar a las Autoridades competentes y a los consumidores y usuarios a través de publicidad suficiente, toda noticia que se tenga respecto de la peligrosidad del producto o servicio de que se trate, si ello es advertido con posterioridad a la introducción de los mismos en el mercado de uso o consumo.

De todos modos, lo anterior no significa que no debe propenderse a la imposición legal una suerte de seguro social obligatorio, que junto con fondos de garantía administrados por el Estado pero engrosados por el aporte de elaboradores y también consumidores y usuarios, permitiría eventualmente reparar las consecuencias dañosas que tuviesen por causa fuente la plataforma fáctica descripta. Es lo que calificada doctrina del Derecho de Seguros y del Consumo, con Rubén y Gabriel Stiglitz a la cabeza, viene propiciando en Argentina desde el Primer Congreso Internacional de Derecho de Daños celebrado en la sede de la Facultad de Derecho y Ciencias Sociales de la Universidad de Buenos Aires en 1989.

Sin embargo, en orden a desalentar la posible indolencia que generase en quien introduce riesgos en la sociedad global esta suerte de aseguramiento social que se ha descripto, ello debe ir acompañado de medidas paralelas sancionatorias, como ser multas administrartivas, privación de licencias, derecho de repetición o regreso de las compañías aseguradoras contra el causante del daño, etc.. Es que como advierte Blankenburg en un estudio realizado en la ex Alemania Occidental hacia comienzos de 1980 referido al estado de la cuestión en aquél país, el seguro debería proteger contra los riesgos que escapan a toda previsión, pero no debería inducir a que se incurra en los mismos riesgos contra los que se concede protección ${ }^{75}$.

Relacionado con esto, ha sabido afirmar el español Manuel Olivencia que el seguro de responsabilidad civil, que de eso se trata, va concibiéndose, cada vez más, como una garantía de indemnización a favor de la víctima; el interés del perjudicado pasa a primer plano, por encima de una concepción egoísta en favor exclusivo del asegurado. La eventual obligatoriedad del seguro sería ciertamente un dato de este nuevo criterio de justicia ${ }^{76}$.

Es que en la actualidad la Responsabilidad Civil atiende más a la justicia distributiva que a la conmutativa ${ }^{77}$, por ello cuadra predicar que el problema de los riesgos y los daños no es una cuestión de responsabilidad, sino de reparación, como ya escribía Ripert hacia mediados del siglo, en su trabajo acerca de El régimen democrático y el derecho civil moderno, quien llegó a sintetizar que la democracia exige que si no se encuentra quien pueda soportar los riesgos, la colectividad misma los tome a su cargo ${ }^{78}$.

\section{Reflexiones últimas.}

Es dable destacar que al presente, sobre todo en lo que hace al tópico de la responsabilidad derivada de productos elaborados y servicios defectuosos, desarrollos como los esbozados tienen como "causa fuente indirecta" a la eufemística "observación" que el Poder Ejecutivo Nacional ha efectuado en su día al original art. $40 \mathrm{LDC}^{79}$, que en los hechos implicó su veto merced al art. $6^{\circ}$ del Dto. 2089/93.

Tal circunstancia obliga a los operadores jurídicos también a "observar", una vez más, y con detenimiento por cierto, las desgastadas normas de la "Teoría General del Responder" contenidas mayormente en el Código Civil, de modo de hacerlas rendir lo suficiente como para posibilitar lo que voces mucho más autorizadas que la mía han denominado "contratendencia" jurídico científica, de signo valorativamente opuesto tendencia de los poderes políticos

75. Conf. Puig Brutau, José, Fundamentos de Derecho Civil, Bosch, Barcelona, 1983, To II-3, págs. 175 a 177.

76. Conf. Puig Brutau, José, Fundamentos de Derecho Civil, Bosch, Barcelona, 1983, To II-3, págs. 175 a 177).

77. Conf. Lorenzetti, Ricardo L., Medicamentos y responsabilidad civil, La Ley 1989-D, págs. 960 a 968.

78. Conf. ello en Stiglitz, Gabriel A., El riesgo de la empresa y el seguro social, en Derecho de Daños, Obra colectiva en homenaje al Prof. Dr. Jorge Mosset lturraspe, La Rocca, Bs. As., 1989, págs. 119 a 140.

79. En su redacción original prescribía: "Responsabilidad solidaria. Si el daño al consumidor resulta del vicio o defecto de la cosa o de la prestación del servicio responderá el productor, el fabricante, el importador, el distribuidor, el proveedor, el vendedor y quien haya puesto su marca en la cosa o servicio. El transportista responderá por los daños ocasionados a la cosa con motivo o en ocasión del servicio. La responsabilidad es solidaria, sin perjuicio de las acciones de repetición que correspondan. Sólo se liberará total o parcialmente quien demuestre que la causa del daño le ha sido ajena". Adviértase que la finalidad de esta norma, vetada de hecho inconstitucionalmente en Argentina, era teleológicamente análoga a las vigentes y contenidas en los arts. 12, 13 y 28 del Código de Defensa del Consumidor del Brasil. 
constituidos, en orden a posibilitar una tutela axiológicamente valiosa y efectiva de los "vulnerables" de finales de Siglo, esto es los consumidores y usuarios e inclusive subconsumidores y subusuarios - verbigracia, niños, ancianos, destinatarios finales de los productos elaborados, etc. ${ }^{80}$. Y en esta tarea, la reflexión es a la lectura como diez es a uno.

Es que una vez más se verifica que no hay nada más desigual que tratar igual a quienes no son iguales -verbigracia, productores y distribuidores de bienes de consumo o uso masivo como ser franquiciante y franquiciado, en relación a sus destinatarios finales -. Y ello hizo que Couture propusiera en su día que ante la verificación de desigualdades de hecho - verbigracia económicas-, el Derecho debía tender a generar otras desigualdades - de "derecho" - que compensasen a las primeras, lo cual fue receptado en el ámbito - también en su día - del Derecho del Trabajo, y debe serlo ahora en el Derecho del consumidor y del usuario. En palabras de Josserand, la inseguridad material de los contratantes débiles debe recubrirse de seguridad jurídica, debiendo atenderse no sólo al texto normativo, sino también al contexto fáctico, de modo que los avances de la Sociología jurídica se incorporen al entramado de normas y valores y su resultante se incluya como aporte al Derecho vivo, posibilitando todo ello la adecuada solución de los conflictos que genera la conducta en interferencia intersubjetiva.

Por último, y para concluir este trabajo, se me antoja valioso hacer un breve ejercicio de imaginación, consistente en visualizar a las normas que conforman la Teoría del Daño Resarcible como una suerte de camino empedrado que nos permite introducirnos en un callejón, el que conduce al Derecho del Consumidor y del Usuario; empedrado que a los pocos metros se transforma en pavimento asfáltico y estaría representado por la LDC en su redacción original, lo cual nos presentaba una mejor salida del descripto callejón. Pero a poco que se sigue ilusionadamente avanzando nos topamos con una pared, representada por el art. 6 o del Dto. 2089/93 que "observó" - vetó - el referido art. 40 de la LDC. Así los tantos, no debemos desesperanzarnos, dado que situados ante un normativo y aparente callejón sin salida, y recordando que al comienzo del mismo aún contamos con las normas de la Teoría del Responder, debemos tener presente que la salida todavía es posible. Es, hacia atrás, el callejón.
80. Conf. al respecto Ghersi, Carlos A., Modernos conceptos de responsabilidad civil, Ediciones Jurídicas Cuyo, Mendoza, 1995, en especial pp. 212 y 213.

\section{Funções do Estado}

Maxco OFridolin Pammex dos Pantos

Professor de Instituições de Direito Civil da UFRGS - Advogado ${ }^{1}$

\section{SUMÁRIO \\ I- INTRODUÇÃO.}

II - PERSPECTIVA HISTÓRICA. A) Formação poder e das instituições na Idade Antiga. B) Do primado do feudalismo ao primado do absolutismo. C) Evolução da separação de funções na Inglaterra.

III - FUNÇÕES DO ESTADO E SEPARAÇÃO DE FUNÇÕES. 1. Introdução. A) Funções do Estado 1. Considerações Iniciais 2. Função de Chefia de Estado 3. Função de Chefia de Governo. 4. Função Deliberativa 5. Função Administrativa ou Executiva 6. Função Jurisdicional 7. Considerações finais. B) Separação de Funções 1. Considerações Iniciais. 2. Dinâmica do Sistema Presidencialista. 3. Dinâmica do Sistema Parlamentarista. 4. Considerações finais.

IV - CONCLUSÃO GERAL.

$V-B I B L I O G R A F I A$.

1. Trabalho apresentado no curso de mestrado em Direito da UFRGS, na disciplina de Teoria Geral de Direito Público, ministrada pelo professor Almiro do Couto e Silva.

\section{I - Introdução} tir, princípios emprestados de outras ciências humanas. tando o princípio de que o homem nasce livre e dotado de vontade e livre arbítrio, bastando a natureza humana para titulá-lo como igual a seus semelhantes, com os mesmos direitos e deveres.

Aproveita da sociologia o conceito de grupo, que é formado de duas ou mais pessoas que interagem entre si, na busca de uma finalidade. Em todo o grupo, constata-se a realidade inarredável da necessidade de liderança. Ou seja, de que havendo duas ou mais pessoas alguém lidera, decide ou governa, sendo acatado neste exercício po, em sua essência, divide-se entre líderes e liderados, coordenadores e coordenados, presente trabalho, adota, sem discu-

Assim, ele se socorre da filosofia adopelos demais. Melhor dizendo, todo o gru- 